\title{
Smoking Prevalence in Cienfuegos City, Cuba
}

\author{
Mikhail Benet MD PhD, Alfredo Espinosa MD PhD, Alain Morejón MD MS, Emiliano Diez MD MS, Orlando Landrove MD MS, \\ Pedro O. Ordúñez MD PhD
}

\begin{abstract}
INTRODUCTION Over the last 40 years, high smoking prevalence has been reported throughout Cuba, including in Cienfuegos city in the central part of the island.

OBJECTIVE Determine smoking prevalence and potential associated risk factors in Cienfuegos city for 2010-2011.

METHODS A descriptive cross-sectional study was conducted in Cienfuegos city in the context of CARMEN (Collaborative Action for Risk Factor Prevention \& Effective Management of Non-communicable Diseases), a PAHO multi-country initiative for a multidimensional approach to chronic non-communicable diseases. Participants totaled 2193 (aged 15-74 years), randomly selected through complex probabilistic three-stage sampling. Variables examined in relation to smoking included age, sex, skin color, civil status and educational level.
\end{abstract}

RESULTS Approximately $25 \%$ of those surveyed were smokers $(30.3 \%$ of men and $21.0 \%$ of women). For men, prevalence was highest in the groups aged 25-34 and 55-64 years; for women, in the group aged 45-54 years. Concerning skin color, smoking rates were higher among black and mestizo persons (29.5\%); and concerning civil status, higher among those who were separated, widowed or divorced (30.0\%). Smoking prevalence fell with higher educational level; in keeping with that trend, the university-educated group had the lowest prevalence (16.2\%).

CONCLUSIONS Although one in four Cienfuegos residents aged $\geq 15$ years smoked in 2010-2011, prevalence there is lower than in previous surveys. Knowledge of differences observed in age, sex, skin color, civil status and educational level can be useful for planning future smoking prevention and control actions.

KEYWORDS Tobacco, smoking, prevalence, health surveys, risk factor surveillance, Cuba

\section{INTRODUCTION}

WHO estimates that in the early 21 st century, smoking has continued at epidemic levels. Close to $30 \%$ of the global population aged $\geq 15$ years smokes, despite a downward trend observed in recent years, primarily in high-income countries.[1] Studies on smoking prevalence, however, have reported extremely heterogeneous data, making comparisons difficult in many cases. The main reasons for these difficulties are: differences in sampling methods, definitions of smoking, the population's demographic structure, age groups included, as well as time and place of study.[1]

Ever since data became available on smoking in Cuba, prevalence has been considered high. The earliest national-level data on smoking prevalence date back to 1978. A survey conducted by the Ministry of Domestic Trade showed that $68.9 \%$ of the population aged $\geq 17$ years smoked.[2] In 1980, a study by the Cuban Consumer Research Institute found a prevalence of 52.9\%.[3] In 1984 , a national prevalence of $42.2 \%$ was registered by the same Institute, which by 1988 had fallen to $40.1 \%$ (47.3\% of men and $25.5 \%$ of women).[4]

In 1995, the First National Survey on Risk Factors and Chronic Diseases found that $36.8 \%$ of Cuba's urban population aged $\geq 18$ years smoked (48.1\% of men and $26.3 \%$ of women).[5] In 2001 , the Second National Survey reported a decrease in the same population, to $31.9 \%$, with lower rates for both men $(41.4 \%)$ and women (23.0\%).[6]

The Cuban Consumer Research Institute reported smoking prevalence in the population aged $\geq 17$ years in Cienfuegos Province of $43.6 \%$ in $1984,45.5 \%$ in 1988 and $40.3 \%$ in 1989 , all rates above the national averages.[7] The first report from the Cienfuegos Global Project, conducted in 1991-1992, cited a prevalence of $33 \%(\mathrm{Cl} 95 \% 30.7-35.3)$ in the population aged $\geq 15$ years in the province's capital city of Cienfuegos.[8]

Since then, the municipality of Cienfuegos (2012 population 160,000 ) has been systematically monitored, first by the
Cienfuegos Global Project[8] in the 1990s, and from the turn of the century by a PAHO's multi-country initiative on chronic non-communicable diseases (NCDs), CARMEN (Collaborative Action for Risk Factor Prevention \& Effective Management of NCDs).[9] Through this process, abundant data have also been collected on prevalence of risk factors associated with various NCDs in this municipality. Among these, smoking prevalence in Cienfuegos has been closely monitored and is one of the most studied subjects throughout the province, using periodic surveys conducted with the CARMEN methodology.

National estimates of current smoking prevalence are not as precise. Recent local studies found over $30 \%$ in the adult population aged $\geq 17$ years,[10] while preliminary data from the Third National Survey on NCD risk factors present figures close to $24 \%$,[11] similar to several other local reports.[12] National prevalence by age group, sex, skin color, civil status and educational level is also presently unknown.

A study was conducted in the second stage of the CARMEN initiative to determine smoking prevalence and potential associated risk factors in Cienfuegos city for 2010-2011.

\section{METHODS}

Using the CARMEN framework, a descriptive cross-sectional study was conducted in 2010-2011 in Cienfuegos city, the capital of Cienfuegos Province (in central Cuba, some 240 kilometers east of Havana). The city had a population of 126,273 inhabitants aged 15-74 years when the study began.[13]

A desired sample size of 2400 was calculated: 12 groups with 200 participants each, formed by 10 -year age subgroups (15-24, 25-34, 35-44, 45-54, 55-64, 65-74), each including both sexes. Complex probabilistic three-stage sampling was used. Sample units were census districts, areas and sections (made up of 5-7 houses) in Cienfuegos city. Individuals in each household were then selected probabilistically, ensuring that each group had the 
number planned. Specialists from the local branch of the Provincial Statistics Office participated in all phases of the process. Details of the sampling methods have been published previously.[13]

Data were collected using the CARMEN-recommended questionnaire.[9] The interviewers, health professionals trained for this task, visited households selected for the sample, surveying a total of 2193 individuals.

Variables examined included: age group, sex, self-declared skin color (white; mestizo or black), educational level completed (primary: first to sixth grade; middle school: seventh to ninth grade; high school or middle-level technical training: 10th to 12th grade; university: beyond 12th grade), and civil status (single; married or cohabiting; and separated, widowed or divorced).

Data recorded from questionnaires were first entered into a Microsoft Access database programmed for the study and transferred to the SPSS Complex Samples-15 model for statistical analysis and calculation of estimates with $95 \%$ confidence intervals. The sample was weighted to population subgroup distribution in Cienfuegos city as of study initiation. Rates were adjusted for age and sex. Results were presented in tables and figures, by relative frequencies with their confidence intervals. In some cases, the Pearson chi-square test of independence was applied to compare results among groups. The statistical significance level was set at 0.05 .

The Medical University of Cienfuegos research ethics committee approved the initial project and each theme analyzed in the study. All survey participants gave prior written consent.

\section{RESULTS}

Of the desired sample of 2400 participants, 2193 (91.4\%) were surveyed. Most persons surveyed were in the subgroups aged 35-44 and 45-54 years, women (57.7\%), white (70\%) and married or cohabiting $(59.4 \%)$ (Table 1$)$.

Approximately $25 \%$ of the population surveyed smoked, with higher prevalence in men (30.3\%). Prevalence in men was highest in those aged 25-34 and 55-64; in women, it was highest in those aged $45-54$ years (Table 2).

Higher rates were observed in mestizo or black persons $(29.5 \%)$, and this held true for men $(35.7 \%)$ as well as women $(25.1 \%)$. Prevalence was higher in the separated, widowed or divorced than in those with other civil status. Finally, as educational level rose, smoking prevalence fell, resulting in the lowest rates among university graduates (16.2\%) (Table 3 ).

\section{DISCUSSION}

First the bad news: this study reconfirms that 1 in 4 Cienfuegos city residents aged $\geq 15$ years smokes, still slightly higher than the national prevalence from preliminary data.[11] The good news is that smoking prevalence has been steadily declining over the last two decades (although perhaps not as much as had been hoped). Smoking prevalence has been closely monitored in Cienfuegos city since the early 1990s (33\% in 1991-1992, 31\% in 2001-2002 and $25 \%$ in 2010-2011),[8,9] so it can be confirmed that Cuba's public health goal for 2010 of reducing smoking prevalence to $26 \%$ has been achieved in Cienfuegos.[2]
Table 1: Study population characteristics, Cienfuegos city, Cuba, 2010-2011 ( $n=2193)$

\begin{tabular}{|c|c|c|c|c|c|c|}
\hline \multirow{2}{*}{ Characteristic } & \multicolumn{2}{|c|}{ Men } & \multicolumn{2}{|c|}{ Women } & \multicolumn{2}{|c|}{ Total } \\
\hline & No & $\%$ & No & $\%$ & No & $\%$ \\
\hline \multicolumn{7}{|l|}{ Age group (years) } \\
\hline $15-24$ & 163 & 17.5 & 192 & 15.2 & 355 & 16.2 \\
\hline $25-34$ & 131 & 14.0 & 172 & 13.7 & 303 & 13.8 \\
\hline $35-44$ & 176 & 18.9 & 250 & 19.8 & 426 & 19.4 \\
\hline $45-54$ & 195 & 20.9 & 234 & 18.6 & 429 & 19.6 \\
\hline $55-64$ & 146 & 15.6 & 206 & 16.3 & 352 & 16.1 \\
\hline$>65$ & 122 & 13.1 & 206 & 16.3 & 328 & 15.0 \\
\hline \multicolumn{7}{|c|}{ Skin color (self-declared) } \\
\hline White & 686 & 73.5 & 898 & 71.3 & 1584 & 72.2 \\
\hline Mestizo or black & 247 & 26.5 & 362 & 28.7 & 609 & 27.8 \\
\hline \multicolumn{7}{|c|}{ Educational level (years completed) } \\
\hline $1-6$ & 63 & 6.8 & 131 & 10.4 & 194 & 8.8 \\
\hline $7-9$ & 238 & 25.5 & 327 & 26.0 & 565 & 25.8 \\
\hline $10-12$ & 472 & 50.6 & 566 & 44.9 & 1038 & 47.3 \\
\hline$>12$ & 160 & 17.1 & 236 & 18.7 & 396 & 18.1 \\
\hline \multicolumn{7}{|l|}{ Civil status } \\
\hline Single & 276 & 29.6 & 320 & 25.4 & 596 & 27.2 \\
\hline $\begin{array}{l}\text { Married } \\
\text { or cohabiting }\end{array}$ & 597 & 64.0 & 705 & 56.0 & 1302 & 59.4 \\
\hline $\begin{array}{l}\text { Separated, widowed } \\
\text { or divorced }\end{array}$ & 60 & 6.4 & 235 & 18.7 & 295 & 13.5 \\
\hline Total & 933 & 100 & 1260 & 100 & 2193 & 100 \\
\hline
\end{tabular}

Table 2: Smoking prevalence by age and sex, Cienfuegos city, Cuba, 2010-2011 $(n=2193)$

\begin{tabular}{|c|c|c|c|}
\hline & Men & Women & Total \\
\hline & $\%(95 \% \mathrm{Cl})$ & $\%(95 \% \mathrm{Cl})$ & $\%(95 \% \mathrm{CI})$ \\
\hline \multicolumn{4}{|c|}{ Age group (years) } \\
\hline $15-24$ & $15.3(10.5-21.5)$ & $10.9(7.3-16.1)$ & $13.0(9.6-17.3)$ \\
\hline $25-34$ & $35.1(26.3-45.1)$ & $22.7(16.3-30.6)$ & $28.1(22.2-34.7)$ \\
\hline $35-44$ & $30.1(22.9-38.4)$ & $19.6(14.5-26.0)$ & $23.9(19.5-29.0)$ \\
\hline $45-54$ & $34.4(27.2-42.3)$ & $29.9(24.9-35.5)$ & $31.9(26.7-37.7)$ \\
\hline $55-64$ & $40.4(32.8-48.5)$ & $23.3(18.3-29.2)$ & $30.4(25.6-35.6)$ \\
\hline$>65$ & $34.4(25.2-45.0)$ & $20.4(15.2-26.8)$ & $25.620 .8-31.2)$ \\
\hline $\begin{array}{l}\text { Overall } \\
\text { prevalence* }\end{array}$ & $30.3(26.2-34.8)$ & $21.0(18.0-24.3)$ & $25.0(22.1-28.1)$ \\
\hline
\end{tabular}

* chi square 24.91 ( $1 \mathrm{df}, \mathrm{p}<0.001)$

Table 3: Smoking prevalence by skin color, civil status and educational level, Cienfuegos city, Cuba, 2010-2011 $(n=2193)$

\begin{tabular}{l|c|c|c|} 
& \multicolumn{1}{c|}{ Men } & Women & Total \\
\cline { 2 - 4 } & $\%(95 \% \mathrm{Cl})$ & $\%(95 \% \mathrm{Cl})$ & $\%(95 \% \mathrm{Cl})$ \\
\hline $\begin{array}{l}\text { Skin color (self-declared) } \\
\text { White }\end{array} 28.3(23.8-33.3)$ & $19.3(16.1-23.0)$ & $23.3(20.1-26.7)$ \\
\hline $\begin{array}{l}\text { Mestizo or black } \\
\text { Civil status }\end{array}$ & $25.7(28.4-43.8)$ & $25.1(20.4-30.5)$ & $29.5(25.1-34.3)$ \\
\hline $\begin{array}{l}\text { Single } \\
\text { Married } \\
\text { or cohabitating }\end{array}$ & $31.6(27.1-36.6)$ & $19.5(16.3-23.1)$ & $24.9(21.9-28.1)$ \\
\hline $\begin{array}{l}\text { Separated, wid- } \\
\text { owed or divorced }\end{array}$ & $44.4(33.4-56.0)$ & $26.0(19.9-33.2)$ & $30.0(24.0-36.7)$ \\
\hline $\begin{array}{l}\text { Educational level completed } \\
\text { 1-6 }\end{array}$ & $39.0(27.2-52.1)$ & $31.6(23.7-40.8)$ & $34.2(26.9-42.3)$ \\
\hline $7-9$ & $39.3(32.1-47.1)$ & $29.9(24.0-36.6)$ & $34.1(29.2-39.3)$ \\
$10-12$ & $27.6(22.4-33.5)$ & $19.0(15.9-22.4)$ & $22.8(19.6-26.4)$ \\
\hline$>12$ & $22.8(17.0-29.9)$ & $11.9(7.8-17.60)$ & $16.2(12.7-20.4)$ \\
\hline
\end{tabular}


Smoking declines have been more marked over the last ten years (i.e., between the 2001-2002 and 2010-2011 surveys). These results contrast with statistics from the 1990s, when smoking prevalence remained almost constant (from 1991-1992 to 20012002), in the midst of Cuba's serious economic crisis, despite multiple shortages and the high cost of tobacco products, as well as public education campaigns.[2]

Strategies to combat the smoking epidemic include health information and education, appropriate legislation, and availability of smoking cessation services. Activities have been conducted in all three of these areas at national, provincial and city levels, although much remains to be done.[2,14,15]

One explanation for the more encouraging recent results could be that long-term effects of previous interventions are now being felt at both community and individual levels, $[14,16]$ especially in reducing smoking among younger age groups. However, it is important to remain vigilant. Two main objectives of the antismoking campaign are: reduce the number of young people who start smoking and among those who do pick up the habit, delay onset as long as possible; and reduce the number of current smokers by providing counseling services to help them quit.[15]

It is noteworthy that although men smoke more than women, the steepest decline in smoking has been among men, where prevalence dropped from 43\% in 1991-1992 to 39\% in 2001-2002 and then to $30 \%$ in 2010-2011. Meanwhile, statistics for women smokers have held fairly steady (23\% in 1991-1992, 23\% in 2001-2002 and $21 \%$ in 2010-2011), a fact which should be underscored when prevention/cessation activities are designed for women.[8,17]

The issue of women and smoking has been widely addressed because of negative repercussions in this population. One of the most serious is the recent rise in lung cancer in women in Cuba in general-and women in Cienfuegos Province in particular-making it their primary cause of cancer death.[18] Another often-neglected factor is the accelerated rise in postmenopausal osteoporosis, which causes significant morbidity and disability in older women.[19] In January 2013, the New England Journal of Medicine and the BMJ (formerly British Medical Journal) published new research on smoking risks for women.[20,21]

The higher prevalence found among mestizo and black Cienfuegos residents, already reported as of 1991-1992,[8] could be related to socioeconomic conditions, educational level, or other factors not part of this study. Research on hypertension in Cienfuegos city concluded that there were no differences among white, black and mestizo residents in terms of availability of and access to health services, but there were differences in terms of adherence to therapy, which could also be influenced by socioeconomic and educational factors.[12,22] Our results thus alert us to the need to further investigate associations of skin color, socioeconomic conditions, educational level and other factors, to determine how these may relate to smoking, in order to better target actions to further reduce smoking in these populations.

Another interesting result has been the higher prevalence of smokers among separated, widowed or divorced persons, as was observed in the 1991-1992 survey.[8] Differences by civil status cannot be interpreted in isolation, since other variables such as sex, age, educational level, drinking prevalence and socioeconomic status can also influence results. This does not mean that this should not be considered as a factor, particularly because it has been a consistent result over time, at least in Cienfuegos city.[8]

The higher smoking prevalence among less educated participants (34\%), twice as high as for university-educated persons $(16 \%)$, although predicted, underscores the importance of education in curbing risk behaviors. In 1991-1992, smoking prevalence in non-university-educated individuals (37\%) was higher than among university graduates (25\%).[8] The good news is that higher educational levels achieved over the last 20 years appear to have effectively acted as a protective factor. In the $2010-2011$ CARMEN survey $18.1 \%$ of the adult Cienfuegos population was university educated,[9] up from $9.1 \%$ in 1991 (unpublished data). In any case, the educational level of the smoking population is an important factor to consider in designing and organizing antismoking media campaigns, as well as in the language and forms of expression used in these campaigns.

\section{CONCLUSIONS}

Smoking prevalence in Cienfuegos city was markedly lower in 2010-2011 than in previous surveys. Knowledge of differences in smoking prevalence by age group, sex, skin color, civil status and educational level can be useful for instituting new actions in public health and tobacco control in this Cuban municipality. 1 .

\section{REFERENCES}

1. World Health Organization. WHO Report on the Global Tobacco Epidemic, 2008.The MPOWER package. Geneva: World Health Organization; 2008

2. Suárez N. Paradojas, controversias, discurso y realidad del tabaquismo en Cuba. Rev Cubana Salud Pública. 2011 Jan-Mar;37(1)120-31. Spanish.

3. Cuban Consumer Research Institute (CU). Programa para la prevención y control del tabaquismo. Havana: Instituto Cubano de Investigaciones y Orientación de la Demanda Interna (CU); 1988. Spanish.

4. Chapman S. Tobacco Control in the Third World: a resource atlas. Penang (MY): International Organization of Consumer Union; 1990. 242 p.

5. National Hygiene, Epidemiology and Microbiology Institute (CU). Encuesta nacional de fac- tores de riesgo Cuba 1995 Havana: National Hygiene, Epidemiology and Microbiology Institute (CU); Ministry of Public Health (CU); 1995. Spanish.

6. National Hygiene, Epidemiology and Microbiology Institute (CU); Ministry of Public Health (CU). Encuesta nacional de factores de riesgo. Cuba 2000-2001. Havana: National Hygiene, Epidemiology and Microbiology Institute (CU); 2002. Spanish.

7. Suárez N, Carballoso M, Rodríguez DM. Legislación para el control del tabaquismo en Cuba. Rev Cubana Salud Pública [Internet]. 2008 Mar [cited 2014 Feb 20]; [about 4 screens]. Available from: http://bvs.sld.cu/revistas/spu/vol34_3_08/ spu06308.htm. Spanish.

8. Espinosa AA, Espinosa AD. Factores de riesgo asociados en los fumadores. Resultados de la medición inicial del Proyecto Global de Cienfuegos. Rev Cubana Med. 2001;40:162-8. Spanish.

9. Benet M, Morejón A, Espinosa AD, Landrove OO, Peraza D, Ordúñez PO. Factores de riesgo para enfermedades crónicas en Cienfuegos, Cuba 2010. Resultados preliminares de CARMEN II. Medisur. 2010 Mar-Apr;8(2):56-9. Spanish.

10. Suárez N, Campos E. Prevalencia y percepción del riesgo del tabaquismo. Área de salud del Policlínico Dr. Jorge Ruiz Ramírez, Ciudad de La Habana. 2007. Rev Cubana Salud Pública. 2010 May-Jun;36(2):125-31. Spanish.

11. Reed G. New Survey Results Enhance Cuba's NCD Surveillance: Mariano Bonet MD. MEDICC Rev. 2011 Oct;13(4):11-3.

12. Marimón ER, Orraca O, Casanova MC, Paredes R, Mendoza M. Prevalencia de factores de 
riesgo de enfermedades no transmisibles. Rev Ciencias Médicas. 2013 Mar-Apr;17(2):2-12. Spanish.

13. Silva LC, Benet $M$, Morejón A, Ordúñez $P$. An Efficient Sampling Approach to Surveillance of Non-Communicable Disease Risk Factors in Cienfuegos, Cuba. MEDICC Rev. 2012;14(4):36-9.

14. Espinosa AD. Experiencias y resultados del Proyecto Global de Cienfuegos. Rev Cubana Salud Pública. 2011;37(5 Suppl):S619-30. Spanish.

15. Espinosa $A D$, Ordúñez $P$, Peña $F$. El Proyecto Global de Cienfuegos. Una estrategia local de intervención comunitaria. Rev Cubana Med Gen Integral. 1993 Jan;9(3):258-64. Spanish.

16. Ministry of Public Health (CU). Tabaquismo: Plan integral para su prevención y control. Havana: Ministry of Public Health (CU); 2008. Spanish.

17. Ordúñez P, Barceló A, Bernal JL, Espinosa AD, Silva LC, Cooper RS. Risk factors associated with uncontrolled hypertension: Findings from the base line CARMEN survey in Cienfuegos, Cuba. J Hypertens. 2008 Apr;26(4):663-71.

18. National Health Statistics and Medical Records Division (CU). Anuario Estadístico de Salud 2011. Havana: Ministry of Public Health (CU); 2012. Spanish.
19. Romero AJ. Asistencia clínica al adulto mayor. 2nd ed. Havana: ECIMED; 2012. 272 p. Spanish.

20. Schroeder SA. New Evidence that cigarette smoking remains the most important health hazard. N Engl J Med. 2013 Jan 24;368(4):389-90.

21. Women who smoke like men, die like men. BMJ. 2013 Jan 30;346:f543.

22. Ordúñez $P$, Muñoz JL, Espinosa AD, Silva LC, Cooper RS. Ethnicity, education and blood pressure in Cuba. Am J Epidemiol. 2005 Jul $1 ; 162(1): 49-56$.

\section{THE AUTHORS}

Mikhail Benet Rodríguez (corresponding author: mikhail@infomed.sld.cu), physiologist with a doctorate in health sciences. Full professor, Medical University of Cienfuegos (UCMC), Cuba.

Alfredo Espinosa Brito, internist with a doctorate in medical sciences. Distinguished professor and researcher, Gustavo Aldereguía Lima University Hospital, UCMC, Cienfuegos, Cuba.

Alain Morejón Giraldoni, internist with a master's degree in emergency medicine. Associate professor, UCMC, Cienfuegos, Cuba.
Emiliano Diez Martínez de la Cotera, physician with a master's degree in emergency medicine. Assistant professor, UCMC, Cienfuegos, Cuba.

Orlando Landrove Rodríguez, physician with a master's degree in epidemiology, Non-communicable Disease Division, Ministry of Public Health. Associate professor, National School of Public Health, Havana, Cuba.

Pedro 0. Ordúñez García, internist specializing in public health, with a doctorate in medical sciences. Full professor, UCMC, Cienfuegos, Cuba. Advisor, chronic disease prevention and control, PAHO, Washington, DC.

Submitted: September 11, 2013

Approved for publication: July 29, 2014

Disclosures: None

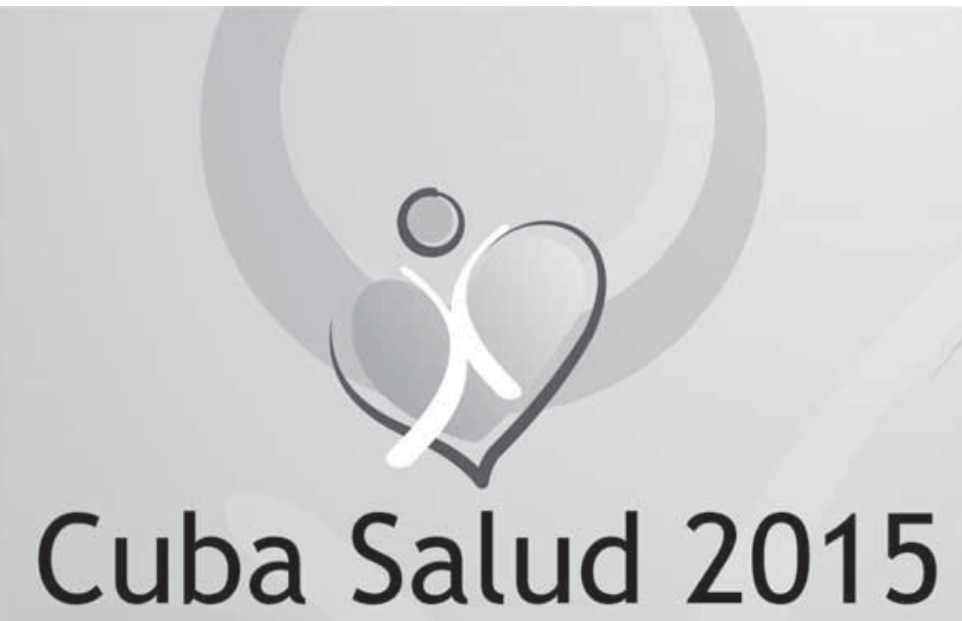

INTERNATIONAL CONFERENCE ON PUBLIC HEALTH April 20-24, 2015

Havana's International Convention Center

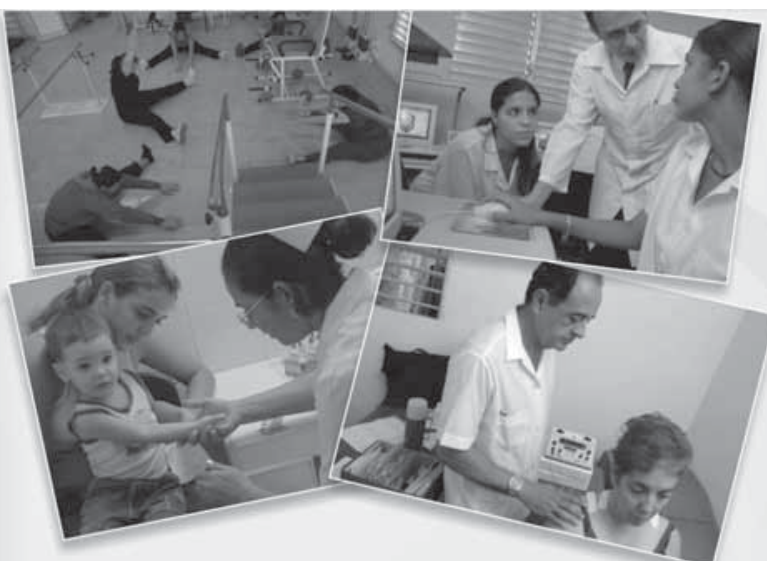

Main themes:

Health policy, health promotion, health system transformation, health care management, disaster medicine, medical education, health technology

\section{Sponsors/Organizers:}

World Health Organization, Pan American Health Organization, Cuban Ministry of Public Health, Cuban Academy of Sciences, Cuban Ministry of Science, Technology and the Environment, THEnet

\section{Conference languages: Spanish and English \\ Information: convencionsalud2015@infomed.sld.cu - http://www.convencionsalud2015.sld.cu US professionals may need US government licenses to participate.}

